\title{
Staphylococcus fleurettii sp. nov., isolated from goat's milk cheeses
}

\author{
Christine Vernozy-Rozand, ${ }^{1}$ Christine Mazuy, ${ }^{1}$ Hélène Meugnier, ${ }^{2}$ \\ Michèle Bes, ${ }^{2}$ Yves Lasne, ${ }^{3}$ Franz Fiedler, ${ }^{4}$ Jerome Etienne ${ }^{2}$ \\ and Jean Freney ${ }^{2}$
}

Author for correspondence: Jean Freney. Tel: +33472110762 . Fax: +33472110764 e-mail: jfreney@laennec.univ-lyon1.fr

\footnotetext{
1 Unité de Microbiologie Alimentaire et Prévisionnelle, Ecole Nationale Vétérinaire de Lyon, 1 avenue Bourgelat, BP 83, 69280 Marcy I'Etoile, France

2 EA 1655, Centre National des Toxémies à Staphylocoques, Faculté de Médecine Laennec, 69372 Lyon cedex 08, France

3 Laboratoire des Radioisotopes, Hôpital Edouard Herriot, Place d'Arsonval, 69437 Lyon cedex 03, France

4 Institut für Genetik und Mikrobiologie, Lehrstuhl für Mikrobiologie, Mariast. 1a, 80638 Munich, Germany
}

\begin{abstract}
A new coagulase-negative and novobiocin-resistant species of the genus Staphylococcus, Staphylococcus fleurettii, isolated from raw-milk cheeses, is described. This species is differentiated from the other novobiocin-resistant staphylococci on the basis of ribotype and intergenic transcribed spacer patterns, DNA-DNA reassociation reactions, cell wall composition and phenotypic characteristics. S. fleurettii could be distinguished by its oxidase activity, by its ability to produce acid aerobically from D-trehalose, D-mannose, D-turanose and maltose and by its inabililty to produce acid from D-cellobiose. The type strain of S. fleurettii is CIP $106114^{\top}$ (= DSM 13212').
\end{abstract}

Keywords: Staphylococcus fleurettii sp. nov., goat's milk cheeses

\section{INTRODUCTION}

A total of 29 species and 8 subspecies are already recognized in the genus Staphylococcus, as listed in the 9th edition of Bergey's Manual of Determinative Bacteriology (Holt et al., 1994). In addition, seven new staphylococcal species have been validly published since 1992 (Staphylococcus muscae, Staphylococcus pasteuri, Staphylococcus piscifermentans, Staphylococcus pulvereri, Staphylococcus vitulinus, Staphylococcus lutrae and Staphylococcus condimenti). Four new subspecies have been recently described: Staphylococcus sciuri subsp. carnaticus, $S$. sciuri subsp. rodentium, Staphylococcus hominis subsp. novobiosepticus and Staphylococcus carnosus subsp. utilis.

Within the cluster of coagulase-negative staphylococci, 16 novobiocin-resistant species or subspecies (Staphylococcus arlettae, Staphylococcus cohnii subsp. cohnii, S. cohnii subsp. urealyticum, Staphylococcus equorum, Staphylococcus gallinarum, Staphylococcus kloosii, Staphylococcus lentus, S. pulvereri, Staphylococcus saprophyticus subsp. saprophyticus, S. saprophyticus subsp. bovis, S. sciuri subsp. sciuri, S. sciuri subsp. carnaticus, $S$. sciuri subsp. rodentium, $S$. vitulinus, Staphylococcus xylosus and S. hominis subsp. novobiosepticus) have been established so far.

Staphylococcus species have been isolated from various mammals and birds, as well as from food of animal origin. It is likely that novel species will be discovered if additionnal host organisms and new environments are examined. As the presence of coagulase-negative staphylococci or their toxins in goat's milk cheese poses a possible health hazard, it was of interest to identify and study the enterotoxigenicity of coagulasenegative staphylococci isolated from milk and cheeses (Vernozy-Rozand et al., 1996b).

In this paper, a new taxonomic group of novobiocinresistant staphylococci is described. These bacteria were isolated from goat's milk cheeses in a previous study (Vernozy-Rozand et al., 1996a). They were allocated on the basis of their physiological and biochemical properties, cell wall composition and genetic relatedness to the other oxidase-positive and novobiocin-resistant staphylococcal species.

\section{METHODS}

Bacterial strains. Six strains $\left[81,90,91,125,193\right.$ and $241^{\mathrm{T}}(=$ CIP $106114^{\mathrm{T}}=$ DSM 13212 $)$ ] were isolated from goat's 
Table 1. DNA relatedness between Staphylococcus fleurettii and other species in the genus Staphylococcus

Abbreviations: ATCC, American Type Culture Collection, Manassas, VA, USA; CCM, Czech Collection of Microorganisms, Masaryk University, Brno, Czech Republic; CIP, Collection of Bacterial Strains of Institut Pasteur, Paris, France; DSM, DSMZ -Deutsche Sammlung von Mikroorganismen und Zellkulturen, Braunschweig, Germany; JCM, Japan Collection of Microorganisms, RIKEN, Wako, Japan.

\begin{tabular}{|c|c|c|}
\hline Species and subspecies & Strain & $\begin{array}{c}\text { Relative binding with } \\
\text { labelled DNA from } \\
\text { CIP } 106114^{\mathrm{T}}(\%) \\
\text { at } 55^{\circ} \mathrm{C}^{*}\end{array}$ \\
\hline \multirow[t]{6}{*}{ S. fleurettii } & 81 & 86 \\
\hline & 90 & $96 \cdot 6$ \\
\hline & 91 & 100 \\
\hline & 125 & 87 \\
\hline & 193 & 100 \\
\hline & $241^{\mathrm{T}}\left(\right.$ CIP $\left.106114^{\mathrm{T}}\right)$ & 100 \\
\hline S. vitulinus & ATCC $51145^{\mathrm{T}}$ & $44(20)$ \\
\hline S. intermedius & CCM $5739^{\mathrm{T}}$ & 37 \\
\hline S. caseolyticus & ATCC $13548^{\mathrm{T}}$ & 35 \\
\hline S. cohnii subsp. urealyticum & ATCC $49330^{\mathrm{T}}$ & 32 \\
\hline S. sciuri subsp. rodentium & ATCC $700061^{\mathrm{T}}$ & $32(12)$ \\
\hline S. sciuri subsp. sciuri & ATCC $29062^{\mathrm{T}}$ & $32(10)$ \\
\hline S. sciuri subsp. carnaticus & ATCC $700058^{\mathrm{T}}$ & $31(10)$ \\
\hline S. lentus & ATCC $29070^{\mathrm{T}}$ & 29 \\
\hline S. chromogenes & CCM $3387^{\mathrm{T}}$ & 24 \\
\hline S. simulans & $\mathrm{CCM} 2705^{\mathrm{T}}$ & 24 \\
\hline S. capitis subsp. capitis & CCM $2734^{\mathrm{T}}$ & 23 \\
\hline S. hyicus & CCM $2368^{\mathrm{T}}$ & 21 \\
\hline S. aureus & CCM $885^{\mathrm{T}}$ & 20 \\
\hline S. carnosus & DSM $20501^{\mathrm{T}}$ & 20 \\
\hline S. equorum & DSM $20674^{\mathrm{T}}$ & 18 \\
\hline S. gallinarum & CCM $3572^{\mathrm{T}}$ & 17 \\
\hline S. schleiferi subsp. schleiferi & ATCC $43808^{\mathrm{T}}$ & 17 \\
\hline S.felis & ATCC $49168^{\mathrm{T}}$ & 15 \\
\hline S. hominis & DSM $20328^{T}$ & 15 \\
\hline S. xylosus & $\mathrm{CCM} 2738^{\mathrm{T}}$ & 15 \\
\hline S. arlettae & DSM $20671^{\mathrm{T}}$ & 14 \\
\hline S. epidermidis & CCM 2124 & 14 \\
\hline S. saprophyticus & CCM $883^{\mathrm{T}}$ & 14 \\
\hline S. schleiferi subsp. coagulans & $\mathrm{JCM} 7470^{\mathrm{T}}$ & 14 \\
\hline S. capitis subsp. ureolyticus & ATCC $49326^{\mathrm{T}}$ & 13 \\
\hline S. lugdunensis & ATCC $43809^{\mathrm{T}}$ & 12 \\
\hline S. pasteuri & ATCC $51129^{\mathrm{T}}$ & 12 \\
\hline S. auricularis & ATCC $33753^{\mathrm{T}}$ & 11 \\
\hline S. kloosii & DSM $20676^{\mathrm{T}}$ & 11 \\
\hline S. piscifermentans & $\mathrm{JCM} 6057^{\mathrm{T}}$ & 11 \\
\hline S. warneri & CCM 2790 & 11 \\
\hline S. cohnii subsp. cohnii & CCM $2736^{\mathrm{T}}$ & 10 \\
\hline S. haemolyticus & CCM $2737^{\mathrm{T}}$ & 10 \\
\hline S. caprae & CCM $3573^{\mathrm{T}}$ & 9 \\
\hline S. muscae & $\mathrm{CCM} 4175^{\mathrm{T}}$ & 9 \\
\hline S. delphini & DSM $20771^{\mathrm{T}}$ & 8 \\
\hline
\end{tabular}

* Values in parentheses were determined at $70{ }^{\circ} \mathrm{C}$. 
milk cheeses made in the Poitou-Charentes region (in France) during a period of 6 months. These strains were not epidemiologically related. The isolation medium was nutrient broth (Oxoid) supplemented with $7 \%(\mathrm{w} / \mathrm{v}) \mathrm{NaCl}$ and blood agar base no. 2 (Oxoid) mixed with $5 \%(\mathrm{v} / \mathrm{v})$ defibrinated ovine blood. The latter was also used for the propagation of all of the isolates.

The 36 type strains of the genus Staphylococcus obtained from the collections given in Table 1 were used for DNA-DNA hybridizations.

All of the strains were maintained as frozen suspensions in glycerol broth at $-25^{\circ} \mathrm{C}$ and also in a freeze-dried state.

Phenotypic characteristics. The following properties were determined by using methods previously described in detail (Hájek, 1976; Hájek et al., 1992): cell and colony morphology and pigmentation on $\mathrm{P}$ agar (Freney et al., 1999); motility; anaerobic growth in thioglycolate medium; production of catalase and oxidase; hydrolysis of aesculin; production of coagulase in rabbit plasma; production of clumping factor, urease, arginine dihydrolase, alkaline phosphatase, heat-labile and heat-stable nucleases, acetoin, $\beta$-galactosidase, ornithine decarboxylase and acid from carbohydrates (arabinose, cellobiose, fructose, fucose, galactose, glucose, glycerol, lactose, maltose, mannose, melezitose, raffinose, salicine, sucrose, trehalose, turanose, xylitol) under aerobic conditions; nitrate reduction; and tolerance to $\mathrm{NaCl}$. In addition, the production of arginine arylamidase, pyrrolidonyl arylamidase, $\beta$-glucuronidase and $N$-acetylglucosaminidase were examined with the ID 32 Staph strip (bioMérieux) (Brun et al., 1990).

Antibiotic susceptibilities. Susceptibility testing with novobiocin, bacitracin, vibriostatic compound O/129, lysozyme and lysostaphin was performed as described previously (Freney et al., 1988; Hájek, 1976). The MICs of 22 different antibiotics were determined by the dilution micromethod with Mueller-Hinton broth (Oxoid). The reference strains Escherichia coli CCM 3988, Staphylococcus aureus CCM 3953, S. saprophyticus CCM 883 and Kocuria (Micrococcus) kristinae CCM 2690 were used as controls.

Enterotoxin production and detection. The detection and production of enterotoxins (i.e. SEA, SEB, $\mathrm{SEC}_{1}, \mathrm{SEC}_{2}$, $\mathrm{SEC}_{3}, \mathrm{SED}$ and SEE) were performed according to methods described previously (Vernozy-Rozand et al., 1996b).

Cell wall analysis. Cells were disintegrated by shaking with glass beads and the cell walls were purified with $4 \%$ SDS by using the procedure of Glauner et al. (1988). For total amino acid analysis, SDS-purified cell walls were hydrolysed with $4 \mathrm{M} \mathrm{HCl}$ for $16 \mathrm{~h}$ at $100{ }^{\circ} \mathrm{C}$. The levels of amino acids were determined with an amino acid analyser (LC 6001; Biotronik). The peptidoglycan structure was deduced from the molar ratios of glutamic acid to glycine, alanine, serine, lysine, glucosamine and muramic acid, respectively (Schleifer \& Kandler, 1972). Phosphorus in cell walls was determined subsequent to acid hydrolyses, according to the method of Ames (1966). The composition of teichoic acids was analysed in hydrofluoric acid (HF) hydrolysates $(60 \%$, $\mathrm{w} / \mathrm{v}, \mathrm{HF}$ ) of cell walls (Anderson et al., 1977) or of extracted and purified teichoic acids in the case of strains 193 and CIP $106114^{\mathrm{T}}$. Extraction of teichoic acids from cell walls and purification were achieved using the methods of Kaya et al. (1985). The analyses of polyols and alditols as peracetylderivatives were performed by GLC. The details of the procedures have been described elsewhere (Webster et al., 1994).
DNA-DNA hybridization. Published methods for the extraction (Heath et al., 1986) and purification of DNA (Brenner et al., 1982) were used. DNA was labelled in vitro by nick translation with tritium-labelled nucleotides (Amersham). The S1 nuclease method (Crosa et al., 1973) was used according to the trichloracetic procedure described in detail elsewhere (Grimont et al., 1980); the reassociation temperature was $55^{\circ} \mathrm{C}$. The hybridization experiments were carried out with labelled DNA from strain CIP $106114^{\mathrm{T}}$ as a probe. The temperature $\left(T_{\mathrm{m}}\right)$ at which $50 \%$ of the reassociated DNA became hydrolysable by the S1 nuclease was determined (Crosa et al., 1973). The difference $\left(\Delta T_{\mathrm{m}}\right)$ between the $T_{\mathrm{m}}$ of the homologous and heterologous reactions is an estimate of the divergence between the two DNAs (Brenner, 1978); this procedure was done twice.

DNA base composition. The $\mathrm{G}+\mathrm{C}$ content of the DNA $(\mathrm{mol} \%)$ was obtained after hydrolysis with nuclease P1 (Sigma) (Gherke et al., 1984) and after reverse-phase chromatography on a Merck-Clevenot chromatograph using the HPLC method as described elsewhere (Peyret et al., 1989). Legionella gratiana strain ATCC 49413, with a $\mathrm{G}+\mathrm{C}$ content of $38.0 \mathrm{~mol} \%$, was included as a standard.

Intergenic transcribed spacer 16S-23S PCR. The 16S-23S rDNA intergenic PCR analysis was performed using the method described by Mendoza et al. (1998).

Ribotyping. Ribotyping was performed as described previously (Regnault et al., 1997).

\section{RESULTS AND DISCUSSION}

The six strains investigated are Gram-positive, spherical cocci that occur singly, in pairs, in short chains and in irregular clusters and that are non-motile and nonspore-forming. All of the strains are able to grow in the presence of $10 \% \mathrm{NaCl}$ and grow both aerobically and anaerobically in the semi-solid Brewer thioglycolate medium. They produce catalase and are resistant to bacitracin, vibriostatic agent $\mathrm{O} / 129$ and lysozyme but are sensitive to lysostaphin. The mean base composition in all of the strains reached $31 \mathrm{~mol} \% \mathrm{G}+\mathrm{C}$. The characteristics mentioned above permit us to include the strains in the genus Staphylococcus.

All of the strains are coagulase-negative in rabbit plasma, heat-stable nuclease- and clumping factornegative and novobiocin-resistant. The DNA-DNA hybridization studies have shown that the six strains are genetically closely related at the species level. However, they are not related to any of the other staphylococcal species.

\section{Description of Staphylococcus fleurettii sp. nov.}

Staphylococcus fleurettii (fleu.rett'i.i. L. gen. n. in honour of the French microbiologist Jean Fleurette for his contribution to the taxonomy of staphylococci).

The description of $S$. fleurettii is based on the results of a study of six strains.

\section{Physiological and biochemical characteristics}

The organism has Gram-positive spherical cells, $0 \cdot 8$ to $1.4 \mu \mathrm{m}$ in diameter, that occur singly, in short chains and in irregular clumps. The organism is non-motile 
Table 2. Variable characteristics of S. fleurettii strains

\begin{tabular}{|lc|}
\hline Characteristic & $\begin{array}{c}\text { No. positive strains/no. } \\
\text { strains tested (\%) }\end{array}$ \\
\hline Colony pigment & $1 / 6(16)$ \\
Acetoin production & $2 / 6(33)$ \\
Alkaline phosphatase & $2 / 6(33)$ \\
Aesculin hydrolysis & $5 / 6(83)$ \\
Acid produced aerobically from: & \\
L-Arabinose & $4 / 6(67)$ \\
D-Xylose & $4 / 6(67)$ \\
\hline
\end{tabular}

and non-spore-forming. Colonies are less than $3 \mathrm{~mm}$ in diameter when the organisms are grown aerobically on $\mathrm{P}$ agar at $37^{\circ} \mathrm{C}$. Colonies on $\mathrm{P}$ agar are usually raised, with ulcerated, irregular centres, opaque and often have sectored or irregular edges; five of the six strains studied produce unpigmented colonies and one strain produces cream pigmentation. Colonies grown on tryptic soy agar are much larger $(8-12 \mathrm{~mm}$ in diameter) and not as irregular as colonies grown on $\mathrm{P}$ agar.

All of the strains are negative for staphylocoagulase, thermonuclease, pyrrolidonyl arylamidase, ornithine decarboxylase, urease, arginine dihydrolase, arginine arylamydase, $\beta$-glucuronidase and $\beta$-galactosidase activities. All strains are negative for aerobic production of acid from the following substrates: D-raffinose, Dgalactose, L-fucose, $\alpha$-lactose, D-melezitose, D-cellobiose, salicine and D-xylitol.

All of the strains are positive for catalase and nitrate reductase activities, modified oxidase activity and aerobic production of acid from the following substrates, D-fructose, maltose, D-mannose, D-trehalose, sucrose and turanose. The variable characteristics of S. fleurettii are listed in Table 2.

\section{Enterotoxin production and detection}

The six strains of S. fleurettii do not produce the seven different enterotoxins that were investigated.

\section{Antibiotic susceptibilities}

In disk diffusion tests, resistance to novobiocin, bacitracin and vibriostatic compound $\mathrm{O} / 129$ is noted. In contrast, all of the strains are sensitive to lysostaphin. All strains are resistant to $1000 \mu \mathrm{g}$ lysozyme $\mathrm{ml}^{-1}$.

As shown by the following MIC values $\left(\mathrm{mg}^{-1}\right)$, all of the strains are susceptible to penicillin $\mathrm{G}(0 \cdot 06-0 \cdot 1)$, gentamicin $(0 \cdot 06-0 \cdot 1)$, kanamycin $(0 \cdot 5)$, tobramycin $(0.06)$, neomycin $(0.06)$, minocycline $(0.06)$, chloramphenicol (4.0), erythromycin $(0 \cdot 06-0 \cdot 5)$, lincomycin
Table 3. Composition of peptidoglycans determined from acid hydrolysates of SDS-purified cell walls

Values are in mol (mol lysine $)^{-1}$. S. aureus was used as a control. The composition of Mur, Glu and Lys was equimolar for all strains.

\begin{tabular}{|lccc|}
\hline Strain & GlcN & Ala & Gly \\
\hline S. fleurettii 193 & 1 & $3 \cdot 6$ & 4 \\
S. fleurettii CIP $106114^{\mathrm{T}}$ & 1 & $3 \cdot 3$ & 4 \\
S. aureus H & $1 \cdot 3$ & $2 \cdot 3$ & $4 \cdot 7$ \\
\hline
\end{tabular}

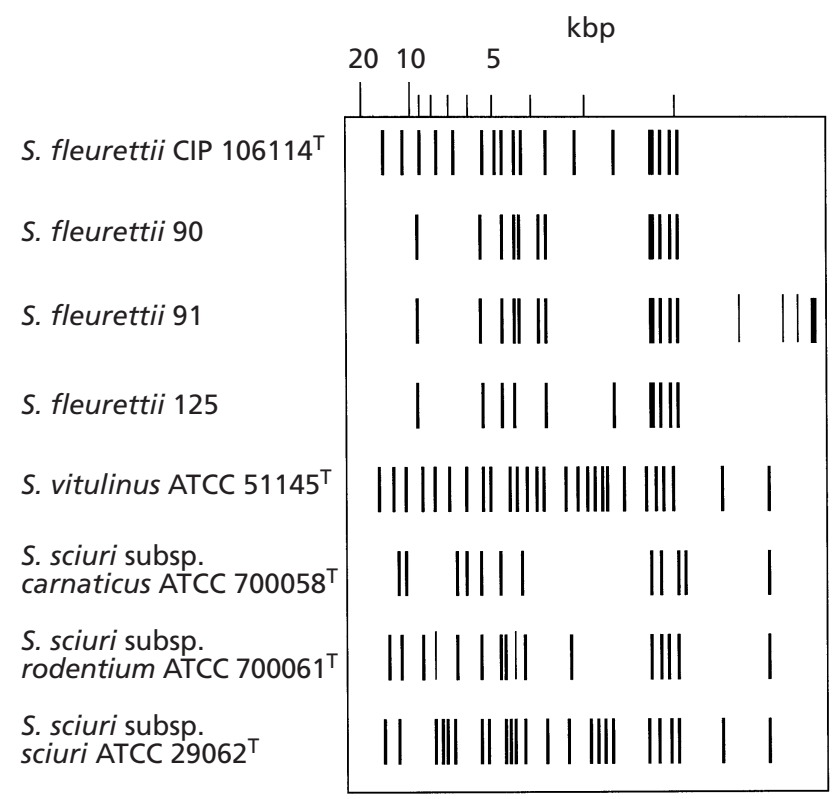

Fig. 1. Schematic representation of ribotype patterns for $S$. fleurettii and type strains of $S$. vitulinus and $S$. sciuri species and subspecies.

$(0 \cdot 06-0 \cdot 5)$, clindamycin $(0 \cdot 06-0 \cdot 1)$, pristinamycin $(0 \cdot 25-10)$, rifampicin $(0 \cdot 1)$, teicoplanin $(0 \cdot 5-20)$, vancomycin $(0 \cdot 5-1 \cdot 0)$ and tetracycline $(0 \cdot 25)$.

Two strains (90 and CIP $106114^{\mathrm{T}}$ ) are resistant to oxacillin and chloramphenicol.

\section{Cell wall analysis}

The composition of peptidoglycans is given in Table 3 . The molar ratios of the amino acids and amino sugars occurring in the peptidoglycans of strains 193 and CIP $106114^{\mathrm{T}}$ are based on lysine. The peptidoglycans tested appear to have tetraglycine interpeptide bridges that also contain alanine.

Lysostaphin is able to hydrolyse the cell walls, whereas 


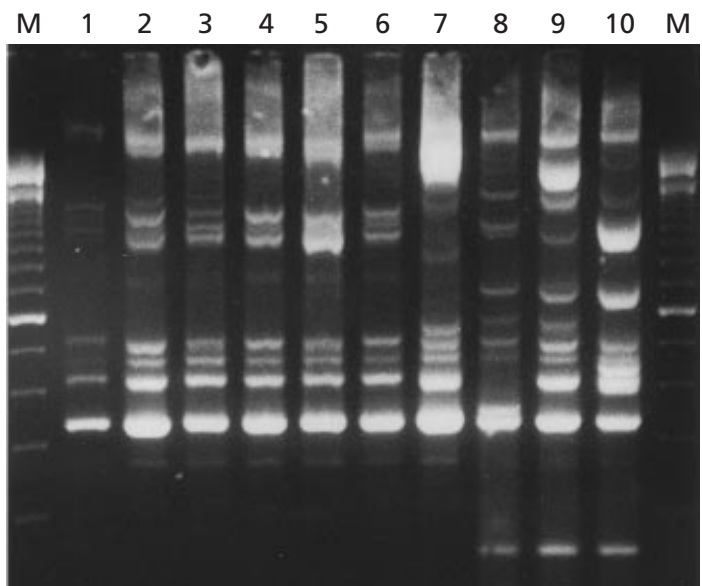

Fig. 2. Intergenic transcribed spacer-PCR of $S$. fleurettii strains and type strains of $S$. vitulinus and $S$. sciuri species and subspecies. Lanes: $M, 100$ bp DNA ladder; 1-6, S. fleurettii strains 81, 90, 91, 125, 193 and CIP 106114 $;$; 7, S. vitulinus ATCC $51145^{\top} ; 8$, S. sciuri subsp. carnaticus ATCC $700058^{\top} ; 9$, S. sciuri subsp. rodentium ATCC $700061^{\top} ; 10$, S. sciuri subsp. sciuri ATCC $29062^{\top}$.

lysozyme has only weak hydrolysis activity, suggesting acetylation of muramic acid (as is the case for S. aureus peptidoglycan).

The composition of the cell walls of strains 193 and CIP $106114^{\mathrm{T}}$ was 0.7 and $0.9 \mu \mathrm{mol}$ phosphorus (mg cell wall) ${ }^{-1}$. Glycerol and glucose were found both in cell walls and in isolated teichoic acids. As a product obtained by HF-hydrolysis of cell walls, isolated teichoic acid $\alpha$-glucosyl-glycerol was recognized by GLC (Fiedler et al., 1981). This indicated that glucose is linked $\alpha$-glycosidically to glycerol phosphate units of poly-(glycerolphosphate) teichoic acids.
Lipoteichoic acids were found and their structure corresponds to that described for staphylococci (Ruhland \& Fiedler, 1990).

\section{DNA-DNA hybridization}

The DNA relationships among the six $S$. fleurettii strains and between strain CIP $106114^{\mathrm{T}}$ and other Staphylococcus species are shown in Table 1. In DNA-DNA hybridization reactions performed under optimal conditions $\left(55^{\circ} \mathrm{C}\right)$, S. fleurettii strains exhibited high levels of DNA similarity (86-100\%). However, the level of DNA relatedness between the new species and the Staphylococcus species were significantly low (8-37\%). Under stringent conditions $\left(70{ }^{\circ} \mathrm{C}\right)$, the levels of DNA similarity were $20 \%$ for $S$. vitulinus, $10 \%$ for $S$. sciuri subsp. sciuri, $10 \%$ for $S$. sciuri subsp. carnaticus and $12 \%$ for $S$. sciuri subsp. rodentium. The $\Delta T_{\mathrm{m}}$ between strain CIP $106114^{\mathrm{T}}$ and S. vitulinus was greater than $5^{\circ} \mathrm{C}\left(5 \cdot 6^{\circ} \mathrm{C}\right)$.

\section{DNA base composition}

The $\mathrm{G}+\mathrm{C}$ content of the DNA of all strains tested varied over a narrow range between 30.9 and $32 \mathrm{~mol} \%$.

\section{Ribotyping}

The ribotypes determined for the six isolates were entered into our database, which contains information on staphylococcal strains (32 species and 4 subspecies). The six $S$. fleurettii strains shared very close rDNA restriction profiles and a core of 10-18 common hybridizing bands (Fig. 1). A similar pattern was observed for three S. fleurettii strains (81, 193 and $241^{\mathrm{T}}$ ). The three other $S$. fleurettii strains presented unique patterns. The ribotypes of the six $S$. fleurettii

Table 4. Characteristics that differentiate $S$. fleurettii from the other novobiocinresistant, oxidase-positive Staphylococcus species

,$+ 90 \%$ or more of the strains are positive; $+/-, 90 \%$ or more of strains are weakly positive;,$- 0-10 \%$ of strains are positive; $d, 11-89 \%$ of the strains are positive. Parentheses indicate that a response is delayed.

\begin{tabular}{|lcccc|}
\hline Characteristic & S. fleurettii & S. vitulinus & S. lentus & S. sciuri \\
\hline Colony size $>$ 6 mm & - & - & - & + \\
Alkaline phosphatase activity & - & - & $(+/-)$ & + \\
Aesculin hydrolysis & $\mathrm{d}$ & $\mathrm{d}$ & + & + \\
Acid produced aerobically from & & & & \\
D-Trehalose & + & $\mathrm{d}$ & + & + \\
D-Mannose & + & - & + & $(\mathrm{d})$ \\
D-Turanose & + & - & $(+/-)$ & $(+/-)$ \\
D-Cellobiose & - & $\mathrm{d}$ & + & + \\
Maltose & + & - & $\mathrm{d}$ & $(\mathrm{d})$ \\
Raffinose & - & - & + & - \\
\hline
\end{tabular}


strains were different from those of the $S$. sciuri and $S$. vitulinus type strains and are distinguishable by the presence of an $S$. fleurettii-specific core of 10 common hybridizing bands (Fig. 1).

\section{Intergenic transcribed spacer 16S-23S PCR (ITS-PCR)}

The $S$. fleurettii patterns shared a core of common fragments and were different from those of the S. sciuri and S. vitulinus type strains (Fig. 2).

\section{Distinguishing characteristics}

S. fleurettii can be phenotypically distinguished from the other novobiocin-resistant and oxidase-positive Staphylococcus species on the basis of the lack of acid production from cellobiose and raffinose and the acid production from trehalose, mannose, turanose and maltose (Table 4).

\section{Description of the type strain}

Type strain $241^{\mathrm{T}}\left(=\mathrm{CIP} 106114^{\mathrm{T}}=\right.$ DSM $\left.13212^{\mathrm{T}}\right)$, isolated from a cheese made from raw goat's milk, has the following characteristics. Colonies are $3 \mathrm{~mm}$ in diameter, unpigmented and raised with ulcerated centres. The type strain produces catalase and is resistant to bacitracin, vibriostatic agent $\mathrm{O} / 129$ and lysozyme but is sensitive to lysostaphin. The type strain is novobiocin-resistant and negative for staphylocoagulase, clumping factor, thermonuclease, alkaline phosphatase, pyrrolidonyl arylamidase, ornithine decarboxylase, urease, $\beta$-glucuronidase and $\beta$-galactosidase activities, arginine utilization and acetoin production. It is negative for aerobic production of acid from the following substrates: D-raffinose, D-galactose, L-fucose, $\alpha$-lactose, D-melezitose, D-cellobiose, salicine and D-xylitol.The type strain is positive for modified oxidase activity, aesculin hydrolysis and aerobic production of acid from the following substrates, Dfructose, maltose, D-mannose, D-trehalose, L-arabinose and D-turanose. The $\mathrm{G}+\mathrm{C}$ content of its DNA is $30 \cdot 7 \mathrm{~mol} \%$.

\section{ACKNOWLEDGEMENTS}

A portion of this work was presented at the 98th General Meeting of the American Society for Microbiology (Abstract D9).

\section{REFERENCES}

Ames, B. N. (1966). Assay of inorganic phosphate, total phosphate and phosphatases. Methods Enzymol 8, 115-118.

Anderson, A. J., Green, R. S. \& Archibald, A. R. (1977). Specific determination of ribitol teichoic acid in whole bacteria and isolated walls of Bacillus subtilis W23. Carbohydr Res 57, C7-C10.

Brenner, D. J. (1978). Characterization and clinical identification of Enterobacteriaceae by DNA hybridization. Prog Clin Pathol 7, 71-117.

Brenner, D. J., McWorter, A. C., Leete Knutson, J. K. \& Steigerwalt, A. G. (1982). Escherichia vulneris: a new species of Enterobacteriaceae associated with human wounds. J Clin Microbiol 15, 1133-1140.

Brun, Y., Bes, M., Boeufgras, J. M. \& 9 other authors (1990). International collaborative evaluation of the ATB 32 Staph gallery for identification of the Staphylococcus species. Zentbl Bakteriol 273, 319-326.

Crosa, J. H., Brenner, D. J. \& Falkow, S. (1973). Use of a singlestrand specific nuclease for analysis of bacterial and plasmid deoxyribonucleic acid homo-and heteroduplexes. $J$ Bacteriol 115, 904-911.

Fiedler, F., Schaffler, M. J. \& Stackebrandt, E. (1981). Biochemical and nucleic acid hybridisation studies on Brevibacterium linens and related strains. Arch Microbiol 129, 85-93.

Freney, J., Brun, Y., Bes, M., Meugnier, H., Grimont, F., Grimont, P. A. D., Nervi, C. \& Fleurette, J. (1988). Staphylococcus lugdunensis sp. nov. and Staphylococcus schleiferi sp. nov., two species from human clinical specimens. Int $J$ Syst Bacteriol 38, $168-172$.

Freney, J., Kloos, W. E., Hajek, V., Webster, J. A., Bes, M., Brun, Y. \& Vernozy-Rozand, C. (1999). Recommended minimal standards for description of new staphylococcal species. Int J Syst Evol Microbiol 49, 489-502.

Gherke, C. W., McCune, R. A., Gama-Sosa, M. A., Ehrlich, M. \& Kuo, K. C. (1984). Quantitative reversed-phase high-performance liquid chromatography of major and modified nucleosides in DNA. J Chromatogr 301, 199-219.

Glauner, B., Holtje, J. V. \& Schwarz, U. (1988). The composition of the murein of Escherichia coli. J Biol Chem 263, 10088-10095.

Grimont, P. A. D., Popoff, M. Y., Grimont, F., Coynaud, C. \& Lemelin, M. (1980). Reproducibility and correlation study of three deoxyribonucleic acid hybridization procedures. Curr Microbiol 4, 325-330.

Hájek, V. (1976). Staphylococcus intermedius, a new species isolated from animals. Int $J$ Syst Bacteriol 26, 401-408.

Hájek, V., Ludwig, W., Schleifer, K. H., Springer, N., Zitzelsberger, W., Kroppenstedt, R. M. \& Kocur, M. (1992). Staphylococcus muscae, a new species isolated from flies. Int J Syst Bacteriol 42, 97-101.

Heath, L. S., Sloan, G. L. \& Heath, H. E. (1986). A simple and generally applicable procedure for releasing DNA from bacterial cells. Appl Environ Microbiol 51, 1138-1140.

Holt, J. G., Krieg, N. R., Sneath, P. H. A., Staley, J. T. \& Williams, S. T. (editors) (1994). Bergey's Manual of Determinative Bacteriology, 9th edn. Baltimore: Williams \& Wilkins.

Kaya, S., Araki, Y. \& Ito, E. (1985). Characterization of a novel linkage unit between ribitol teichoic acid and peptidoglycan in Listeria monocytogenes cell walls. Eur J Biochem 146, 517-522.

Mendoza, M., Meugnier, H., Bes, M., Etienne, J. \& Freney, J. (1998). Identification of Staphylococcus species by $16 \mathrm{~S}-23 \mathrm{~S}$ rDNA intergenic spacer PCR analysis. Int J Syst Bacteriol 48, 1049-1055.

Peyret, M., Freney, J., Meugnier, H. \& Fleurette, J. (1989). Determination of $\mathrm{G}+\mathrm{C}$ content of DNA using HPLC for the identification of staphylococci and micrococci. Res Microbiol 140, 467-475.

Regnault, B., Grimont, F. \& Grimont, P. A. D. (1997). Universal ribotyping method using a chemically labelled oligonucleotide probe mixture. Res Microbiol 148, 649-659. 
Ruhland, G. J. \& Fiedler, F. (1990). Occurrence and structure of lipoteichoic acids in the genus Staphylococcus. Arch Microbiol 154, 375-379.

Schleifer, K. H. \& Kandler, O. (1972). Peptidoglycan types of bacterial cell walls and their taxonomic implications. Bacteriol Rev 36, 407-477.

Vernozy-Rozand, C., Mazuy, C., Perrin, G., Haond, F., Bes, M., Brun, Y. \& Fleurette, J. (1996a). Identification of Micrococcaceae isolated from goat's milk and cheese in the Poitou-Charentes region. Int J Food Microbiol 30, 373-378.
Vernozy-Rozand, C., Mazuy, C., Prevost, C., Lapeyre, G., Bes, M., Brun, Y. \& Fleurette, J. (1996b). Enterotoxin production by coagulase-negative staphylococci isolated from goat's milk and cheese. Int J Food Microbiol 30, 271-280.

Webster, J. A., Bannerman, T. L., Hubner, R. J., Ballard, D. N., Cole, E. M., Bruce, J. L., Fiedler, F., Schubert, K. \& Kloos, W. E. (1994). Identification of the Staphylococcus sciuri species group with EcoRI fragments containing rRNA sequences and description of Staphylococcus vitulinus sp. nov. Int J Syst Bacteriol 44, 454-460. 